DOI: https://doi.org/10.32839/2304-5809/2020-12-88-5

УДК 340.172 .177

Хмара M.B.

Міжнародний економіко-гуманітарний університет імені академіка Степана Дем'янчука

\title{
МЕДИЧНЕ ПРАВО В КОНТЕКСТІ АКТУАЛЬНИХ ПРОБЛЕМ БІОЕТИКИ: ПЕРИНАТОЛОГІЧНИЙ АСПЕКТ
}

\begin{abstract}
Анотація. Досліджено правовий складник біоетики, реалізований у медичному праві як новаційному спрямуванні юридичної науки, у конкретизації до перинатологічних питань. Проаналізовано змістове, функціональне, цільове співвідношення біоетики і медичного права. Охарактеризовано предметно-методологічну специфіку біоюриспруденції. Розглянуто зміст і проблематику правової перинатології у конкретизації до актуальних морально-етичних і правотворчих завдань. Продемонстровано, що підгрунтям дивергентності медичних, правових, фрілософрько-правових, фрілософрсько-етичних, релігійних поглядів на допоміжні репродуктивні технології є розбіжності в уявленнях про природу зачаття, подружніх стосунків, моменту виникнення права на охорону життя ембріона людини, колізія між правом жінки на вільне прийняття рішень щодо можливості дітонародження та правом на охорону життя ембріона, правами сурогатної матері і біологічних батьків. Відзначено необхідність удосконалення правового регулювання застосування допоміжних репродуктивних технологій щодо низки вимог (договір про сурогатне материнство, відповідальність біологічних батьків).
\end{abstract}

Ключові слова: біоетика, медичне право, біоюриспруденція, правова перинатологія, штучне переривання вагітності, допоміжні репродуктивні технології.

Khmara Mila Stepan Demianchuk International University of Economics and Humanities

\section{MEDICAL LAW IN THE CONTEXT OF BIOETHICS CURRENT ISSUES: PERINATOLOGY ASPECT}

Summary. The study researches legal constituent of bioethics that is implemented in medical law interpreted as an innovative direction of legal science and in specialization of perinatology issues. The author presents bioethics as a branch of interdisciplinary research of the issues that arise as a result of biotechnologies development. The paper points out that bioethics is an attractor to implement humanistic opportunities of medical law, its catalyst element, basis to constitute and reflect legal rules, mediator between ethics, medicine and law. The author highlights that generally accepted complementarity of morals and law in social relations regulation is justified with the relationship of bioethics and medical law, necessity in legislative recognition of bioethics rules and harmonization of medical law regulations with bioethics principles. The study emphasizes on the expressiveness of object field dealing with bioethics of naturally-legal principles and promotion in their expression within regulative and legal aspect. The paper stresses on the significance of bioethics principles in medical law constitution that presents the introduction of biojurisprudence concept. Fundamental principle of biojurisprudence is the acceptance of human's life as the highest bio-social value within the unity of physical and moral characteristics. The author presents the aim of biojurisprudence as the provision and defense with legal means because of intensive development of biology and medicine. The paper gives rationale for legal perinatology as a significant constituent of biojurisprudence. Legal perinatology researches legal aspects of human's life from the moment of fertilization till the bearing due to the development of secondary reproductive technologies. Basing on the analysis of current legislation and moral and ethic aspects of the issue the author gives the reason for conclusion concerning with the need to improve legal regulation of secondary reproductive technologies use according to the list of requirements (surrogate maternity agreement, biological parents' responsibility) represented in different aspects. The study demonstrates background of divergence in medical, legal, philosophical and legal, philosophical and ethical, religious positions and secondary reproductive technologies. This background concerns with the differences in interpretations of fetation nature, marriage relations, moment of accrual of the right to protection of human embryo life, contradiction between women's right to independent decision making dealing with child-bearing and right to the protection of human embryo life, surrogate mother's rights and biological parent's rights.

Keywords: bioethics, medical law, biojurisprudence, legal perinatology, artificial termination of pregnancy, secondary reproductive technologies.

$\Pi$ остановка проблеми. Характерний для другої половини XX - початку XXI ст. стрімкий розвиток медично-природничого знання зумовив загострення етичних і правових проблем у медичній сфері, заснованих на суперечностях між розумінням лікарської справи як мистецтва підтримання і захисту життя та їі розвитком як індустрії надання медичних послуг, функціонування якої зумовлено комерційно-корпоративними інтересами і соціальними запитами, низка з яких е дискутивними щодо морально-етичних вимог. Фундаментальну колізію сучасності утворило осмислення людини як істоти наділеною вільною волею, орієнтованої на самовизначення та необхідність їі підпорядкування закріпленим у культурній традиції моральним нормам. Актуалізацію розгляду етично-правових проблем медицини спричинила релятивізація ціннісних підвалин суспільного життя. 
Означене зумовило розвиток біоетики, біомедичної етики - міждисциплінарної сфери наукових досліджень, предметна область якої охоплюе біологічні, медичні, етичні, юридичні проблеми, що потребують комплексного розгляду у перетині змістових полів. Чільне місце серед завдань біоетики посіли етична легітимація медицини i посередництво між iï гуманістичним, природничонауковим, правовим складниками. 3 огляду на осмислення у культурній і правовій традиціях життя людини як найвищої цінності, особливого значення набули питання, пов'язані з впливом новітніх біотехнологій на його зародження, трансформацію, припинення.

Обгрунтовуючи актуальність теми публікації відзначимо, що особливого значення вона набуває у суспільствах перехідного типу з властивими їм дивергентністю законотворчості і правозастосування, легітимізованих аксіонормативних програм і соціальної практики, «імпортованих» соціонормативних моделей і закріплених у культурно-релігійній традиції етично-моральних норм.

Аналіз досліджень та публікацій. Актуальні проблеми біоетики у вітчизняному соціокультурному і правовому контекстах стали предметом уваги дослідників на межі XX-XXI ст. Так, у фрілософрській площині питання розглядали В. Винник-Остапишин (2014), В. Кулініченко (2001), Ю. Кундієв (1999), Т. Кучера (2014), О. Ліщинська-Милян (2004), С. Пустовіт (2009), В. Чешко (2001). Предметну специфріку біоюриспруденції охарактеризовано А. Бабаніним (2005), Н. Болотіною (1999), В. Вандишевим (2016), О. Галкіним (2011), О. Гринчишин (2015) [2], О. Губановою (2016), Л. Дешко (2006), О. Кашинцевою (2009) [6], Б. Логвиненком (2012), О. Мережком (2008), М. Новіковою (2016), I. Сенютою (2006), В. Середюком (2015) [12], С. Стеценком (2013) [16], В. Цимбалюком (2017) [19]. Теоретико-правовий аспект біоетичних проблем проаналізовано М. Слабим і Д. Терешкевич (2007), Т. Тарахонич та О. Тарахоничем (2012), Я. Триньовою (2014). Біоетичні аспекти міжнародного права, розглянуто Б. Островською $(2017,2018,2019)$, В. Третьяковою (2013), К. Шанталій (2020).

Значний корпус утворюють публікації, присвячені окремим аспектам біоетичних засад правового регулювання. Так, питання паліативної допомоги, евтаназії та ортаназії досліджено Ю. Губським, А. Царенко (2009), Б. Островською (2017), Я. Триньовою $(2011,2012,2013)$; трансплантології - О. Кашинцевою (2006), М. Ковальським (2017), Б. Островською; репродуктивної медицини, захисту права на життя ненародженої дитини - Ю. Гоголь (2008) [1], О. Егерт (2020) [4], В. Марковою (2014), Б. Островською (2016) [9], Н. Старіковою (2014) [15], Г. Терешкевичем, I. Васильевою (2012) [17]; біоетичні аспекти інформованої згоди пацієнта на медичне втручання - В. Сакалом (2012).

Водночас, стрімкий розвиток біотехнологій та інтеграція України у європейське соціокультурне і правове поле спонукають до подальшого дослідження біоетичних аспектів медичного права у конкретизації до вітчизняних законотворчості і правозастосування, зокрема у вирішенні перинатологічних питань.
Отже, метою пропонованої статті є розгляд правового складника біоетики, реалізованого в медичному праві як новаційному спрямуванні юридичної науки, у конкретизації до перинатологічних питань.

Виклад основного матеріалу дослідження. Органічність обгрунтування предмету, структури i фонкцій медичного права згідно принципів біоетики зумовлена гуланістичним потенціалом медицини як системи наукових знань і практичної діяльності, спрямованих на охорону здоров'я і життя, та права, яке у перфекціоністському вимірі відображае природничо-правові принципи. Таким чином, біоетика постае атрактором і каталізатором реалізації гуманістичних потенціалів медицини і медичного права, основою рефлексії їх етичних засад. Висловимо міркування, що саме біоетика увиразнюе природно-правові виміри медичного права і сприяе їхньому віддзеркаленню у нормативній площині. Зокрема принципам біоетики відповідають такі норми природного права людини як право на життя, продовження роду, особистісну гідність, вільне волевиявлення.

Не випадково, значущими для конституювання медичного права на засадах біоетики є такі принципи останньої як: визнання автонолії індивіда та його права розпоряджатися власним здоров'ям, погоджуватись 3 певними програмами лікування або ж відмовитись від нього; $і н$ форлована згода, що передбачае добровільний і свідомий дозвіл паціента на медичне втручання в свое життя на основі якнайбільш вичерпної інформації про власне здоров'я, одержаної від фахівців; мінімалізація шкоди, завданої при медичному втручанні; приниип блага, що передбачає намір лікаря здійснювати дії, спрямовані виключно на покращення стану паціента; принuиn справедливості, що закріплюе рівне ставлення до паціентів і справедливий розподіл ресурсів при наданні медичної допомоги; принцип людської гідності, спрямований на гарантування гідного ставлення до неповнолітніх та паціентів навіть за умови втрати ними фрізичної чи психічної діездатності; інтегративний принцип, оріентований на забезпечення недоторканності психофізичної цілісності людини, упередження порушень особистісної ідентичності на основі втручань у геном; приниип вразливості, що передбачае рефлексію над вразливістю і прийдешністю людського життя, мотивуе коректне ставлення до людей з обмеженими психічними чи фрізичними можливостями.

Необхідність конвергенції медичного права та біоетики обгрунтовуе загальновизнана взаємодоповнюваність моралі $і$ права у регулюванні суспільних відносин. Так, важливими е такі хрестоматійні еднальні чинники моралі і права як системність; спільність мети, функціонального призначення і базових цінностей; утвердження свободи, справедливості, рівності, гуманізму; ідентичність кола адресатів; збіг приписів щодо певних дій. До правового закріплення біоетичних принципів спонукає необхідність забезпечення їх дієвості, яку у правовій сфері гарантуе держава завдяки фіксованості правових норм у юридичних актах, чіткості правових критеріїв оцінки дій і вчинків у координатах «правомірно- 
го - неправомірного», «законного - незаконного», «осудного - неосудного», встановлення юридичної відповідальності та регламентованості її реалізації законом.

Важливо відзначити обопільність взаємодії медичного права і біоетики, сприяння права суспільному закоріненню моральних норм в медичній сdрері і збагачення медичного права біоетичними принципами.

Значущість біоетичних принщипів у конституюванні медичного права зумовила введення до наукового обігу поняття «біоетика в праві», біоюриспруденція, правнича біоетика, засадничим принципом якої $е$ визнання життя людини основоположною цінністю [16, с. 259]. Посутнім е зауваження автора терміну польського науковця Романа Токарчика, що біоюриспруденція осмислюе людину не лише як фрізичну, а й як духовну істоту в едності «душі, блага, справедливості», що спонукає розгляд правових норм у зв'язку з сенсами ії соціокультурного буття [20, s. 12]. Одним з найбільш емних, на нашу думку, є визначення біоюриспруденції С. Стеценком як новітнього науково-правового утворення, «в основі якого лежить сприйняття життя людини як найвищої біосоціальної цінності, метою якого є забезпечення та захист правовими засобами життя людини у зв'язку з інтенсивним розвитком біології та медицини» [16, с. 260].

Отже, маємо підстави стверджувати, що специфрікуючими ознаками біоюриспруденції у порівнянні $з$ медичним правом, оріентованим на законодавче регламентування суспільних відносин, що виникають в процесі реалізації медичної діяльності, є яскраво виражений аксіологічний характер і послідовна редлексія над життям людини як найвищою цінністю у його зв'язку 3 культурними традиціями і концептуалізаціями у теологічному, dрілософрському, культурологічному, біологічному дискурсах.

3 аксичним характером біоюиспруденції пов'язана їі аргументність, заснована на осмисленні співвідношення релігійних, загальнокультурних, морально-етичних джерел прав людини у їх діалектичному співвідношенні.

Предметом правового регулювання у межах біоюриспруденщії $є$ такі проблеми біоетики як репродуктивні технології, одержання інформованої згоди пацієнта та забезпечення його прав, зокрема й у випадку обмеженої дієздатності; трансплантологія, вакцинація, генні інженерія і терапія, клонування; регуляція часу смерті, що конституює іii mри основних структурних частини: правову перинатологію; правову солатологію; правову танатологію [19, с. 300].

Згідно усталеної точки зору, під правовою перинатологією слід розуміти «складову частину біоюриспруденщії, що досліджуе правові аспекти життя людини 3 моменту запліднення до народження» [16, с. 262].

Однією 3 їі проблем є штучне переривання вагітності, морально-етичний аспект якої пов'язаний 3 правом на життя ненародженої дитини і визначенням статусу ембріона. Так, у релігійній традищії неприпустимість абортів аргументовано цінністю людського життя 3 моменту зачаття, створенням Богом неповторної безсмертної душі в його момент. Науковим обIрунтуванням заборони штучного переривання вагітності є його негативний вплив на репродуктивне здоров'я жінки і створення у момент зачаття людського організму 3 індивідуальним генетичним кодом, хромосомним набором, транскрипцією ДНК і синтезом білків.

Показово, що у преамбулі Конвенції про права дитини, ухваленій Генеральною асамблеєю ООН 29 листопада 1989 р., стверджуеться, що згідно Декларації прав дитини остання потребує спеціальної охорони і піклування, включаючи правовий захист як до, так і після народження.

Означене спонукає до порушення проблеми виникнення права на життя як правового явища і права на життя ембріона людини, яка знаходить різне вирішення у наукових дослідженнях. Так, посутнім аспектом останніх є встановлення моменту, в який людська істота набуває права на охорону життя: 3 народження, з моменту запліднення чи у певні періоди внутрішньоутробного розвитку (з 14 дня після зачаття [7, с. 11], з четвертого тижня 3 початком серцебиття, 3 шостого тижня 3 реєстрацією електрофізіологічної активності мозку, з 22 тижня, коли плід набуває багатьох ознак майбутньої людини [16, с. 263]).

Відзначимо відсутність у вітчизняному законодавстві чіткого визначення початку життя людини, виникнення права на життя і регламентації правового статусу ембріона. Опосередкованою ï дефініцією можна вважати положення п. 6 ст. 281 Цивільного кодексу України, за яким «штучне переривання вагітності, якщо вона не перевищуе дванадцяти тижнів, може здійснюватися за бажанням жінки. У випадках, встановлених законодавством, штучне переривання вагітності може бути проведене при вагітності від дванадцяти до двадцяти двох тижнів» [18]. Аналогічне положення містить ст. 50 Закону України «Основи законодавства про охорону здоров'я», згідно якої операція штучного переривання вагітності (аборт) може бути проведена за бажанням жінки у закладах охорони здоров'я при вагітності строком не більше 12 тижнів, а у випадках, встановлених законодавством, при вагітності від дванадцяти до двадцяти двох тижнів [8].

Як зазначає Б. Островська, з позицій «цивільного права відсутність в ембріона статусу фрізичної особи зводить його правовий статус до рівня регулювання речового права, а власне ембріона розглядають у контексті права власності як річ, тобто як об’єкт, а не суб'єкт правовідносин», що уможливлює потрактування репродуктивного права жінки як розпорядження життям ще не народженої дитини як власним тілом [9, с. 141]. На думку дослідниці, подібна позиція є хибною, позаяк «реалізація цього суб'єктивного права не може конкурувати 3 правом на життя ембріона, оскільки ембріон людини <...> є самостійною людською особистістю, яка від зародження має весь комплекс неповторних людських генів, що визначають його, наявні вже зараз, проте розвиватимуться в майбутньому, а також певні фрізичні та психічні якості» [9, с. 141-142].

Водночас, важливим аспектом проблеми $€$ утвердження права жінки на вільний вибір виношування чи не виношування плоду, тобто права репродуктивного вибору як прояву моральної автономії особистості у питаннях сексуальності та дітонародження. 
Із правовою перинатологією пов'язані проблеми допоміжних репродуктивних технологій - штучного запліднення і сурогатного материнства, заснованих на маніпулящіях з гаметами поза організмом людини задля запліднення та народження дитини, які досі не отримали всебічного регулювання в законодавстві України. Так, згідно п. 7 ст. 281 Цивільного кодексу України «повнолітні жінка або чоловік мають право за медичними показаннями на проведення щодо них лікувальних програм допоміжних репродуктивних технологій згідно з порядком та умовами, встановленими законодавством» [18] У п. 1 ст. 290 Цивільного кодексу України гарантовано право повнолітньої діездатної фізичної особи на донорство, зокрема репродуктивних клітин. Згідно ст. 48 «Основ законодавства про охорону здоров'я», «застосування штучного запліднення та імплантації ембріона здійснюеться $<. .>>$ за медичними показаннями повнолітньої жінки, з якою проводиться така дія, за умови наявності письмової згоди подружжя, забезпечення анонімності донора та збереження лікарської таємниці» [18].

Важливим аспектом проблеми є захист прав dimeй, народжених із застосуванням допоміжних репродуктивних технологій. Так, у ст. 123 Сімейного кодексу України «Визначення походження дитини, народженої в результаті застосування допоміжних репродуктивних технологій» відзначено, що у разі народження дружиною дитини, зачатої в результаті застосування допоміжних репродуктивних технологій, здійснених за письмовою згодою її чоловіка, він записуеться батьком дитини. У випадку перенесення в організм іншої жінки ембріона людини, зачатого подружжям (чоловіком та жінкою) в результаті застосування допоміжних репродуктивних технологій, батьками дитини $е$ подружжя. Подружжя визнається батьками дитини, народженої дружиною після перенесення в її організм ембріона людини, зачатого iї чоловіком та іншою жінкою в результаті застосування допоміжних репродуктивних технологій [13]. Означені нормативно-правові акти доповнюе Наказ MO3 «Про затвердження Порядку застосування допоміжних репродуктивних технологій в Україні» від 09.09.2013, заснований на раніше проаналізованих законодавчих статтях [10].

Водночас, невирішеними питаннями правового регулювання застосування допоміжних репродуктивних технологій лишаються: конкретизація правових підстав взаємодії реципіентів і донорів, їхніх прав, відповідальності, обов'язків; окреслення права дітей, народжених унаслідок застосування репродуктивних технологій, на одержання індрормації про біологічне батьківство; верхня межа віку жінки-реципіента. Дискутивними є обов'язковість сімейного статусу жінки-реципієнта та офіційна фріксація шлюбу біологічних батків. Конкретизації потребуе поняття «медичні показання» до застосування репродуктивних технологій. Подальшого розгляду очікують кримінально-правові аспекти штучного запліднення.

Невповні урегульованою і сповненою правових колізій лишаеться проблема сурогатного материнства - штучного запліднення яйцеклітини з наступною імплантаціею ембріона, отриманого від генетичних батьків, в матку сурогат- ної матері (повна або гестаційна сурогатність) або використання яйцеклітини сурогатної матері для виношування плоду іншою жінкою (часткова або гендерна сурогатність).

Згідно «Положення про запліднення in vitro і трансплантацію ембріонів», прийнятого Всесвітньою медичною асоціацією у 1987 р., умовою застосування технології $є$ фрізична неможливість виношування плоду жінкою. Згідно міжнародних стандартів, умовою сурогатного материнства є добровільна інформована згода сторін - учасників застосування репродуктивної технології.

$\mathrm{y}$ вітчизняній правовій традиції окремі аспекти сурогатного материнства врегульовуе Сімейний кодекс України, в п. 2 ст. 123 якого зазначено, що «у разі перенесення в організм іншої жінки ембріона людини, зачатого подружжжям (чоловіком та жінкою) в результаті застосування допоміжних репродуктивних технологій, батьками дитини є подружжя» [13], а материнство, за таких підстав, оспорюванню не підлягає (п. 2 ст. 139 Сімейного кодексу України) [13]. Водночас, правову колізію створюють «Правила реестрації актів цивільного стану в Україні», затверджені Наказом Міністерства юстиції України від 18 жовтня 2000 р., згідно яких у випадку «народження дитини жінкою, якій в організм було перенесено ембріон людини, зачатий подружжям у результаті застосування допоміжних репродуктивних технологій, державна реестрація народження проводиться за заявою подружжя, яке дало згоду на таке перенесення», однак «одночасно 3 документом, що підтверджуе фракт народження дитини цією жінкою, подаеться заява про іїі згоду на запис подружжя батьками дитини» [11].

Недоліком чинних нормативно-правових актів $е$ відсутність чіткого визначення сурогатного материнства і неврегульованість часткової або гендерної сурогатності. Так, у ст. 139 Сімейного кодексу України відзначено, що жінка, котра записана матір'ю дитини, може оспорити своє материнство (п. 1, ст. 139), а жінка, «яка вважає себе матір'ю дитини, має право пред'явити позов до жінки, яка записана матір'ю дитини, про визнання свого материнства» (п. 2, ст. 139) [13].

Правового урегулювання потребують підстави виникнення правовідносин з сурогатного материнства. На думку ряду науковців, з цією метою варто розробити моделі договору про сурогатне материнство, з наступним закріпленням у Сімейному кодексі України [13]. Необхідним е визначення переліку осіб, які вправі вдаватися до сурогатного материнства. Врегулювання потребуе використання послуг з сурогатного материнства іноземними громадянами. Невирішеними у вітчизняному законодавстві е питання відповідальності за порушення правил сурогатного материнства, відмови подружжя від дитини, народженої сурогатною матір'ю, смерті або розлучення подружжя під час виношування плоду, смерті дитини до народження, народження неповноцінної дитини.

Не менш складними е морально-етичні аспекти допоміжних репродуктивних технологій, аналізовані з різних світоглядних і дискурсивних позицій. Так, доцільність їхнього застосування підтверджуе реалізація для безплідного подружжя невід'емного права жінки на материнство, а чоловіка - на батьківство, яке на законодавчому 
рівні закріплено у ст. 49 і ст. 50 Сімейного кодексу України. На користі допоміжних репродуктивних технологій для безплідних пар і суспільства в цілому, їх сприянні усуненню генетичних захворювань акцентовано у «Положенні про запліднення in vitro і трансплантацію ембріонів», ухваленому Всесвітньою медичною асоціацією у 1987 р.

Водночас, згідно релігійної традиції, штучне запліднення і сурогатне материнство суперечать розумінню життя як безцінного Божого дару, прояву Божественної волі, спонукають ставлення до нього як предмету комерційних угод, загрожують не лише духовній цілісності і фрізичному здоров'ю особи, а й подружнім стосункам [14]. Небезпека застосування допоміжних репродуктивних технологій, на думку прибічників традищійних цінностей, полягає й у тому, що, втручаючись у процес зародження нового життя, людина прирівнює себе до Творця [5]. Не воднораз прибічниками теологічної позиції відзначено, що за умови запліднення in vitro дитина зачинається не унаслідок «еднання в любові», а лікарських процедур [3].

Водночас, в «Основах соціальної концепції УПЦ» відзначено припустимість інсемінації статевими клітинами чоловіка, бо вона не руйнує цілісності шлюбного союзу, тоді як гетерологічне запліднення натикається на категоричне заперечення як таке, що порушуе святість таїнства шлюбу та $є$ різновидом перелюбу [14]. 3 погляду християнської етики посутньо, що використання донорського матеріалу спонукає батьківську i материнську безвідповідальність і створюе колізію наявності в дитини як "соціальних", так i «біологічних" батьків. Морально неприпустимим вважається знищення зайвих ембріонів, які 3 моменту зачаття є повноцінними людськими істотами. Як неприродне, несумісне 3 цілісністю шлюбу і гідністю дітонародження засуджується сурогатне материнство, що зумовлюе майбутні страждання дитини.

У цілому аргументи прибічників релігійних поглядів сприймаються принциповим запереченням допоміжних репродуктивних технологій й слугують не удосконаленню їх правового регулювання, а редлексії в аспекті морально-етичних питань.

Чільне місце проблеми застосування допоміжних репродуктивних технологій посіли у фрілософрсько-правовому та етико-правовому дискурсах, низку положень яких інтегровано біоетикою i біоюриспруденцією.

Так, як комерційний процес, схожий до проституції, сурогатне материнство розглядають А. ван Некерн та Л. Зил у праці «Етика сурогатного материнства: репродуктивна фонкція» (1995) [4]. На нівеляцію сурогатним материнством ціннісного та емоційного складників дітонародження, приниження жіночої гідності і руйнацію суспільних моральних засад вказують Е. Андерсон (1990) і Ф. Тарзоглу [4].

Поширеним $є$ обговорення сурогатного материнства у зв'язку з проблемами свободи і справедливості. Так, згідно лібертаріанського підходу, сурогатне материнство виправдовуе вільна угода сторін. Водночас, останню заперечуе мотивація сурогатної матері, пов'язана з матеріальною скрутою. У ракурсі утилітарної теорії, договір про сурогатне материнство є справедливим, бо сурогатна мати і подружжя одержують певну вигоду [4].
У низці концепцій контраргументом сурогатному материнству слугуе перетворення дитини на товар, предмет комерційної угоди, що руйнуе поняття людської гідності і «норми батьківської любові» (Е. Андерсен, 1990) [4]. Чільне місце у фрілософрько-правових та етичних дискусіях посідають питання відповідальності біологічних батьків та відмови від дитини після ії народження.

Заборону сурогатного материнства обстоюють представниці феміністичного руху, за переконанням яких воно $є$ фрормою патріархальної експлуатації жінки, травматичним маніпулюванням її тілом в інтересах третіх осіб, уможливленим економічними, політичними і символічними реаліями гендерної нерівності.

Як засвідчує аналіз наведених аргументів, лише частина із них може бути усунута шляхом правового урегулювання, зокрема розробки моделі договору про сурогатне материнство та утвердження правових норм, що унеможливлюють відмову від дитини, народженої сурогатною матір'ю. Інші ж положення і докази слугують проблематизації питання в площині різноманітних дискурсивних практик та увиразненню його етичних аспектів, що, врешті, реалізує завдання біоетики в сучасному культурному полі.

Висновки. Отже, можемо зробити висновок, що біоетика як галузь міждисциплінарних досліджень проблем, що виникають унаслідок розвитку біотехнологій, є атрактором реалізації гуманістичного потенціалу медичного права, їі каталізатором, основою конституювання i pedpлексії правових норм; медіатором між етикою, медициною i правом. Взаємозв'язок біоетики та медичного права, необхідність законодавчого закріплення біоетичних норм та узгодження норм медичного права з принципами біоетики обгрунтовує загальновизнана взаємодоповнюваність моралі і права в регулюванні суспільних відносин. Важливим є увиразнення в предметному полі біоетики природно-правових засад права і сприяння їхньому відображенню у нормативноправовій площині.

Вагомість біоетичних принципів у конституюванні медичного права обгрунтовуе введення до обігу поняття біоюриспруденція, фрундаментальним принципом якої є визнання життя людини як найвищої біосоціальної цінності у єдності фрізичних і духовних ознак, а метою - його забезпечення і захист правовими засобами у зв'язку 3 інтенсивним розвитком біології та медицини.

Важливим складником біоюиспруденщії $є$ правова перинатологія, яка досліджує правові аспекти життя людини 3 моменту запліднення до народження, у зв'язку із розвитком допоміжних репродуктивних технологій. Аналіз чинного законодавства та морально-етичних аспектів проблеми засвідчує необхідність удосконалення правового регулювання застосування допоміжних репродуктивних технологій стосовно низки вимог (договір про сурогатне материнство, відповідальність біологічних батьків), сформульованих у різних дискурсивних площинах. Продемонстровано, що підірунтям дивергентності медичних, правових, філософрсько-правових, фрілософрсько-етичних, релігійних поглядів на допоміжні репродуктивні технології є розбіжності в уявленнях про природу зачаття, подружніх 
стосунків, моменту виникнення права на охорону життя ембріона людини, колізія між правом жінки на самостійне прийняття рішень щодо дітонародження та правом на охорону життя людського ембріона, правами сурогатної матері і біологічних батьків.
Перспективи подальших досліджень правових складників біоетики, реалізованих в медичному праві, полягають у поглибленому вивченні соматологічних і танатологічних проблем i віднайденні науково обгрунтованих відповідей на виклики сучасності, зокрема щодо вакцинації.

\section{Список літератури:}

1. Гоголь Ю.В. Правове регулювання штучного переривання вагітності: проблемні питання. Науковий вісник Львівського державного університету внутрішніх справ. 2008. № 3. С. 1-9.

2. Гринчишин О.О. Право біоетики як доктрина захисту біологічної цілісності людини. Південноукраӥнський правовий часопис. 2015. № 4. С. 26-29.

3. Гусак П. Моральні та правові аспекти допоміжних репродуктивних технологій. На межі життя і смерті. Вісник № 2 Інституту Родини і Подружнього Життя. Львів : Вид-во ЛБА, 2001. С. $62-66$.

4. Егерт О. Сурогатне материнство - виклик моральним засадам суспільства чи порятунок для безплідних пар. URL: http://jurfem.com.ua/surogatne-materynstvo-etychni-aspekty/ (дата звернення: 01.12.2020).

5. Катковская М.Я. Новые репродуктивные технологии и аксиологические ориентиры православия. URL: http://sobor.by/tehnologii.php (дата звернення: 28.11.2020).

6. Кашинцева О.Ю. Право біоетики та медичне право : новий напрямок наукових досліджень. Часопис Київського університету права. 2009. Вип. 4. С. 202-208.

7. Красицька Л.В. Право громадян України на життя, здоров’я, свободу і особисту недоторканність : автореф. дис. ... канд. юрид. наук : 12.00 .03 - цивільне право і цивільний процес ; сімейне право ; міжнародне приватне право. Харків, 1999. 19 с.

8. Основи законодавства про охорону здоров’я : Закон України № 2801-XII від 19 листопада 1992 року. Відолості Верховної Ради України. 1993. № 4. Ст. 19.

9. Островська Б.В. Право людини на життя від моменту 望 зародження в контексті права та моралі. Філособьські та методологічні проблеми права. 2016. № 2. С. 140-149.

10. Про затвердження Порядку застосування допоміжних репродуктивних технологій в Україні : Наказ Міністерства юстиції України від 09.09.2013. № 787 : поточна редакція - редакція від 11.04.2014, підстава - z0366-14.

11. Про затвердження Правил державної реєстрації актів цивільного стану в Україні : Наказ Міністерства юстиції України від 18.10.2000 № 52/5, поточна редакція - редакція від 02.10.2020, підстава - z0962-20.

12. Середюк В. Правнича біоетика - новий напрям дослідження загальнотеоретичної юридичної науки. Соиіологія права. 2015. № 3-4. С. 219-224.

13. Сімейний кодекс України : Кодекс України, Закон, Кодекс, поточна редакція - Редакція від 03.07.2020, підстава - 720-IX. Відолості Верховної Ради України (ВВР). 2002. № 21-22. Ст. 135.

14. Соціальна концепція УПЦ. URL: http://orthodox.org.ua/page/sots\%D1\%96alna-kontsepts\%D1\%96ya (дата звернення: 01.12.2020).

15. Старікова Н.М. Допоміжні репродуктивні технології : цивільно-правовий вимір. Часопис Київського університету права. 2014. № 4. С. 155-159.

16. Стеценко С. Біоюриспруденція як новий напрям правових наукових досліджень. Публічне право. 2013. № 3(11). C. 259-270.

17. Терешкевич Г., Васильева I. Проблема статусу ненародженої людини в контексті біоетики: державно-правовий аспект. Ефективність державного управління : зб. наук. пр. 2012. Вип. 30. С. 90-96.

18. Цивільний кодекс України : Кодекс України, Закон, Кодекс від 16.01.2003 № 435-IV, поточна редакція редакція від 16.10.2020, підстава - 124-IX. Відомості Верховної Ради України. 2003. № 40-44. Ст. 356.

19. Цимбалюк B.I., Торяник I.I., Ольховський B.О., Данильченко C.I. Сутність, специфіка, принципи та предмет дослідження медико-правової галузі сучасної біоюриспруденції. Актуальні проблели сучасної медицини. Вісник Української медичної столатологічної академії. Право. 2017. Т. 17. Вип. 4(60). С. $312-314$.

20. Biojurysprudencja Księga pamiątkowa dedykowana Profesorowi Romanowi A. Tokarczykowi. Lublin, 2013. III. 425 s.

\section{References:}

1. Hohol Yu.V. (2008). Pravove rehuliuvannia shtuchnoho pereryvannia vahitnosti: problemni pytannia [Legal regulation of induced termination of pregrancy: issues]. Scientific Herald of Lviv State University of Internal Affairs, no. 3, pp. 1-9.

2. Hrynchyshyn O.O. (2015). Pravo bioetyky yak doktryna zakhystu biolohichnoi tsilisnosti liudyny [The law of bioethics as a doctrine to protect biological integrity of a person]. South Ukrainian legal journal (electronic journal), no. 4, pp. 26-29. Available at: http://www.sulj.oduvs.od.ua/archive/2015/4/10.pdf (accessed 06.12.2020).

3. Husak P. (2001). Moralni ta pravovi aspekty dopomizhnykh reproduktyvnykh tekhnolohii [Moral and legal aspects of secondary reproductive technologies]. Visnyk № 2 Instytutu Rodyny i Podruzhnoho Zhyttia. Lviv : Vyd-vo LBA, pp. 62-66.

4. Ehert O. Surohatne materynstvo - vyklyk moralnym zasadam suspilstva chy poriatunok dlia bezplidnykh par [Surrogate maternity is a challenge against social moral principles or salvage of fertility-challenged couples]. Available at: http://jurfem.com.ua/surogatne-materynstvo-etychni-aspekty/ (accessed 06.12.2020).

5. Katkovskaja M.Ja. Novye reproduktivnye tehnologii i aksiologicheskie orientiry pravoslavija [New reproductive technologies and axiological guides of orthodoxy]. Available at: http://sobor.by/tehnologii.php (accessed 06.12.2020).

6. Kashyntseva O.Yu. (2009). Pravo bioetyky ta medychne pravo: novyi napriamok naukovykh doslidzhen [The law of bioethics and medical law: a new trend of research]. Journal of Kyiv University of Law, no. 4, pp. 202-208.

7. Krasytska L.V. (1999). Pravo hromadian Ukrainy na zhyttia, zdorovia, svobodu i osobystu nedotorkannist [The right of Ukrainian citizens to life, health, liberty and personal inviolability] (Abstract from PhD thesis to obtain the degree in specialty of civil law and civil process; family law; international private law). Kharkiv.

8. Osnovy zakonodavstva pro okhoronu zdorovia: Zakon Ukrainy № 2801-XII vid 19 lystopada 1992 roku [Fundamentals of the legislation on Health Care: the Law of Ukraine, No. 2801-XII, 19 November, 1992$] .1993$. Ukrainian Verkhouna Rada's Data, no. 4, p. 19. 
9. Ostrovska B.V. (2016). Pravo liudyny na zhyttia vid momentu yii zarodzhennia v konteksti prava ta morali [The right of a person to life from the moment of birth in the aspect of law and moral]. Philosophical and methodological issues of the law, no. 2, pp. 140-149.

10. Pro zatverdzhennia Poriadku zastosuvannia dopomizhnykh reproduktyvnykh tekhnolohii v Ukraini: Nakaz Ministerstva yustytsii Ukrainy vid 09.09.2013. № 787: potochna redaktsiia - redaktsiia vid 11.04.2014, pidstava z0366-14 [Concerning Approval of the Use of Secondary Reproductive Technologies in Ukraine: The order of the Ministry of Justice, 9 September, 2013, No. 787: current edition - edition, 11 April, 2014, basis z0366-14].

11. Pro zatverdzhennia Pravyl derzhavnoi reiestratsii aktiv tsyvilnoho stanu v Ukraini: Nakaz Ministerstva yustytsii Ukrainy vid 18.10.2000 № 52/5, potochna redaktsiia - redaktsiia vid 02.10.2020, pidstava - z0962-20 [Concerning Approval of the Rules of State Registration of Civil Status Acts in Ukraine: The Order of the Ministry of Justice of Ukraine, 18 October, 2000, No. 52/5, current edition, 2 October 2020, basis z0962-20].

12. Serediuk V. (2015). Pravnycha bioetyka - novyi napriam doslidzhennia zahalnoteoretychnoi yurydychnoi nauky [Justice science is a new research direction of general theoretical justice]. The sociology of law, no. 3-4, pp. 219-224.

13. Simeinyi kodeks Ukrainy: Kodeks Ukrainy, Zakon, Kodeks, potochna redaktsiia - Redaktsiia vid 03.07.2020 [Domestic Relations Law: Codex of Ukraine, Law, Codex, current edition - edition, 3 July, 2020, basis 720-IX]. Ukrainian Verkhouna Rada's Data, 2002, no. 21-22, p. 135.

14. Sotsialna kontseptsiia UPTs [Social conception of OCU]. Available at http://orthodox.org.ua/page/sots\%D1\% 96alna-kontsepts\%D1\%96ya (accessed 06.12.2020).

15. Starikova N.M. (2014). Dopomizhni reproduktyvni tekhnolohii : tsyvilno-pravovyi vymir [Secondary reproductive technologies: civil-legal aspect]. Journal of Kyiv University of Law, no. 4, pp. 155-159.

16. Stetsenko S. (2013). Bioiurysprudentsiia yak novyi napriam pravovykh naukovykh doslidzhen [Bio-legal studies as a new direction of legal research]. Public Law, no. 3(11), pp. 259-270.

17. Tereshkevych H., Vasylieva I. (2012). Problema statusu nenarodzhenoi liudyny v konteksti bioetyky: derzhavnopravovyi aspect [The issue of status of the unborn person in the context of bioethics: state and legal aspect]. The efficiency of state management: proceedings, no. 30, pp. 90-96.

18. Tsyvilnyi kodeks Ukrainy: Kodeks Ukrainy, Zakon, Kodeks vid 16.01.2003 № 435-IV, potochna redaktsiia Redaktsiia vid 16.10.2020, pidstava - 124-IX [Civil Codex of Ukraine: Codex of Ukraine, Law, Codex, 16 January 2003, no. 435-IV, current edition - edition, 16 October, 2020, basis 124-IX]. Ukrainian Verkhovna Rada's Data, 2003, no. 40-44, pp. 356.

19. Tsymbaliuk V.I., Torianyk I.I., Olkhovskyi V.O., Danylchenko S.I. (2017). Sutnist, spetsyfika, pryntsypy ta predmet doslidzhennia medyko-pravovoi haluzi suchasnoi bioiurysprudentsii [The core, special features, principles and subject of research medical and legal sphere of modern bio-legal studies]. Up-to-date issues of modern medicine. Herald of Ukrainian medical dentist academy. Law, vol. 17, no. 4(60), pp. 312-314.

20. Biojurysprudencja Księga pamiątkowa dedykowana Profesorowi Romanowi A. Tokarczykowi [Bio-legal studies. The book sacred to the memory of Professor Roman A. Tokarchyk]. Lublin, 2013. Vol. 3, p. 425. 